\title{
KŁOPOTY Z DEMONAMI
}

Diabeł jest najmodniejszą ze wszystkich istot. Zawsze idzie z duchem czasu, bo to on definiuje, czym ów duch jest. Bo to on jest tym duchem. Jeśli zatem chcemy zrozumieć stan rzeczy, musimy diabła odszukać.

Jest to zadanie dość ryzykowne. Ponieważ nauki społeczne i humanistyczne opierają się na zapominaniu o szatanie, już samo wspominanie o nim może wydawać się nienaukowe. Przed takim zarzutem można się jednak obronić. A nawet jeśli to się nie uda, można z nim żyć. O wiele poważniejsze jest jednak niebezpieczeństwo metafizyczne. Otóż szukając tropów diabła, z konieczności za diabłem podążamy. W tej sytuacji nie sposób stwierdzić, czy to my go tropimy, czy to on nas ku sobie pociaga; czy idziemy jego śladami dlatego, żeby wiedzieć, dokąd idzie, czy też dlatego, że to on chce, żebyśmy za nim podażali. Nigdy nie będziemy w stanie rozstrzygnąć tych wątpliwości, gdyż - jak wynika z rzetelnych świadectw - diabeł jest inteligentny i przebiegły. Już w XIII w. św. Tomasz dowiódł - o czym przypomina Tomasz Stępień - że szatan ma naturę bezcielesną, a jego władza nad materia jest niemal nieograniczona. Do myślenia powinna nam dać także późniejsza konwersacja pomiędzy Mefistofelesem a Czarownica, którą zanotował Johann Wolfgang Goethe:

Cz: Z radości prawiem obłąkana, że widzę znów mości szatana!

M: Zabraniam, aby mnie tak zwano!

Cz: Cóż zawiniło wam to miano?

M: Od dawna w bajki je wpisano, lecz ludzie maja stąd korzyści mało. Zły wprawdzie ich opuścił, lecz zło pozostało.

Świadkiem tej interakcji był znany alchemik (znany na pewno szatanowi), Johann Georg Faust, zakładam więc, że miała ona miejsce gdzieś na przełomie XV i XVI w. Pomijając możliwe, nakładające się na siebie zniekształcenia pamięci (Goethe spisywał tę relację dużo później na podstawie źródeł pośrednich), można przypuszczać, że już wtedy diabeł nie tylko był postacią fikcyjna, lecz także chciał nią być. To demoniczne pragnienie skutecznie urzeczywistnili najwybitniejsi myśliciele 
nowoczesności - począwszy od niemal rówieśnika Fausta, Niccolo Machiavellego. Demonologiczne debaty trwały jeszcze do końca XVII w., ale potem zapomnieliśmy nie tylko o diable, ale również o tym, że o nim zapomnieliśmy.

Wielką rolę odegrały tu także nauki społeczne, które wysłały diabła do świata ludowych fantazji. Typowe pod tym względem było postępowanie nestora polskiej etnografii, Kazimierza Moszyńskiego, który - jak pisze Magdalena Zowczak - traktował demony „równie przedmiotowo i systematycznie, jak cepy i konstrukcje dachowe”.

Dziś już nikt nie okazałby diabłu takiego lekceważenia. Za sprawa Kirsten Hastrup - o czym pisze w tym samym artykule Zowczak antropologia otwiera się na wymiar jeśli nie transcendencji, to wyobraźni i zaczyna traktować demony poważnie. Marek Kurowski zauważa z kolei, że kontemplacja niewiedzy nieuchronnie prowadzi do tego, że szatan powraca również do socjologii. Tak się przynajmniej dzieje u „późnego” Niklasa Luhmanna, który opiera swoją analizę wyróżnicowania się systemu religijnego i moralnego na śmiałej interpretacji upadku aniołów. Powraca ona w jednym z jego najbardziej tajemniczych tekstów, Nakaz Boży jako forma wolności, w którym granice między socjologia a teologia zacieraja się. Wystarczy zatem zmienić nieco perspektywę, a demony zaczynają się jawić jako centralny element naszego świata. Karl Polanyi we fragmencie Wielkiej transformacji, który przedrukowujemy z komentarzem Piotra Korysia, pokazuje, że wolny rynek jest Blake’owskim szatańskim młynem, mielącym od dwustu lat społeczeństwa Zachodu. Gabriela Matuszek zaś, biorąc za przewodnika Stanisława Przybyszewskiego, już u samych początków nowoczesności odkrywa demonizm, który stopniowo wnika w naszą politykę, kulturę, sztukę, wreszcie - w nas samych. W ostatecznym rachunku musimy więc przyznać rację Ernestowi Gellnerowi: dziś diabeł jest wszędzie i wszyscy w niego wierzymy.

Zgodnie ze starą teologiczną prawdą, o demonach należy myśleć, ale nie za dużo. Żeby myślenie o nich samo nie stało się formą opętania, musi nas przybliżać do Boga. Warto tę prawdę potraktować poważnie, tym bardziej że potwierdza ją zarówno nowoczesna teoria systemów (Luhmann), jak i modernistyczna literatura piękna (Przybyszewski). Dlatego nasze rozważania uzupełniamy egzorcyzmami. Zbawienia dla „opętanej socjologii” Tadeusz Szawiel upatruje w filozofii, Michael Burawoy - w zaangażowaniu na rzecz ruchów społecznych, a Peter Berger - na co kładzie szczególny nacisk Stanisław Burdziej, komentując jego głośne teksty - w braku takiego zaangażowania. Całość kończymy dużym blokiem recenzji książek dotyczących polskiej „wielkiej transformacji”, które o demonach taktownie milcza. 
Jedno jest pewne. $Z$ diabłem nie walczy się słowem, ale czynem. Takim czynem ma być nasze pismo. Prześladujące nas demony - dyscyplinarne podziały, brak wielkich pytań, imitacyjność - możemy pokonać tylko razem. Musimy zderzać ze sobą Wschód z Zachodem, Warszawę z Krakowem, Toruń z Gdańskiem i Olsztynem. Musimy zderzać teorię i zaangażowanie, pozytywizm i antypozytywizm, antropologię i prawo, teologię i ekonomię, historię i filozofię, filologie i socjologię. Musimy rozbijać sztuczne skorupy, pod którymi ukryte sa iskry prawdy.

Michał Luczewski Redaktor Naczelny 